\title{
Activation of PPAR $\gamma$ Ameliorates Spatial Cognitive Deficits through Restoring Expression of AMPA Receptors in Seipin Knock-Out Mice
}

\author{
Libin Zhou, ${ }^{1,2 *}$ Tingting Chen, ${ }^{1,2 *}$ Guoxi Li, ${ }^{2}$ Chaoming Wu, ${ }^{3}$ Conghui Wang, ${ }^{2}$ Lin $\mathrm{Li},{ }^{2}$ Sha Sha, ${ }^{2}$ Lei Chen, ${ }^{2}$ George Liu, ${ }^{4}$ \\ and Ling Chen ${ }^{1,2}$ \\ ${ }^{1}$ State Key Laboratory of Reproductive Medicine and ${ }^{2}$ Department of Physiology, Nanjing Medical University, Nanjing 210029, China, ${ }^{3}$ Department of \\ Endocrinology, The Second Affiliated Hospital of Wenzhou Medical University, Wenzhou 325027, China, and ${ }^{4}$ Institute of Cardiovascular Sciences, Peking \\ University and Key Laboratory of Cardiovascular Sciences, China Administration of Education, Beijing 100191, China
}

A characteristic phenotype of congenital generalized lipodystrophy 2 (CGL2) that is caused by loss-of-function of seipin gene is mental retardation. Here, we show that seipin deficiency in hippocampal CA1 pyramidal cells caused the reduction of peroxisome proliferatoractivated receptor gamma (PPAR $\gamma)$. Twelve-week-old systemic seipin knock-out mice and neuronal seipin knock-out (seipin-nK0) mice, but not adipose seipin knock-out mice, exhibited spatial cognitive deficits as assessed by the Morris water maze and Y-maze, which were ameliorated by the treatment with the PPAR $\gamma$ agonist rosiglitazone (rosi). In addition, seipin-nK0 mice showed the synaptic dysfunction and the impairment of NMDA receptor-dependent LTP in hippocampal CA1 regions. The density of AMPA-induced current $\left(I_{\mathrm{AMPA}}\right)$ in CA1 pyramidal cells and GluR1/GluR2 expression were significantly reduced in seipin-nK0 mice, whereas the NMDA-induced current $\left(I_{\text {NMDA }}\right)$ and NR1/NR2 expression were not altered. Rosi treatment in seipin-nK0 mice could correct the decrease in expression and activity of AMPA receptor (AMPAR) and was accompanied by recovered synaptic function and LTP induction. Furthermore, hippocampal ERK2 and CREB phosphorylation in seipin-nKO mice were reduced and this could be rescued by rosi treatment. Rosi treatment in seipin-nKO mice elevated BDNF concentration. The MEK inhibitor U0126 blocked rosi-restored AMPAR expression and LTP induction in seipin-nKO mice, but the Trk family inhibitor K252a did not. These findings indicate that the neuronal seipin deficiency selectively suppresses AMPAR expression through reducing ERK-CREB activities, leading to the impairment of LTP and spatial memory, which can be rescued by PPAR $\gamma$ activation.

Key words: AMPA receptor; long-term potentiation; peroxisome proliferator-activated receptor gamma; seipin; spatial cognitive

\section{Significance Statement}

Congenital generalized lipodystrophy 2 (CGL2), caused by loss-of-function mutation of seipin gene, is characterized by mental retardation. By the generation of systemic or neuronal seipin knock-out mice, the present study provides in vivo evidence that neuronal seipin deficiency causes deficits in spatial memory and hippocampal LTP induction. Neuronal seipin deficiency selectively suppresses AMPA receptor expression, ERK-CREB phosphorylation with the decline of PPAR $\gamma$. The PPAR $\gamma$ agonist rosiglitazone can ameliorate spatial cognitive deficits and rescue the LTP induction in seipin knock-out mice by restoring AMPA receptor expression and ERK-CREB activities.

\section{Introduction}

Congenital generalized lipodystrophy (CGL) is an autosomalrecessive disorder characterized by a near total loss of adipose tissue, insulin resistance, and hypertriglyceridemia (Szymanski et al., 2007). Genome-wide linkage analysis has identified two loci for CGL: CGL1 by mutation in the 1-acylglycerol-3-phosphate-
Received Aug. 28, 2015; revised Nov. 22, 2015; accepted Dec. 18, 2015.

Author contributions: Lei Chen, G. Liu, and Ling Chen designed research; L.Z., T.C., G. Li, C. Wu, C. Wang, L.L., and S.S. performed research; L.Z., T.C., and Ling Chen contributed unpublished reagents/analytic tools; L.Z., T.C., and Ling Chen analyzed data; Ling Chen wrote the paper.

This work was supported by National 973 Basic Research Program of China (Grant 2014CB943303 to Ling Chen) and the National Science Foundation of China (Grants 31171440, 81361120247, and 81471157 to Ling Chen).

The authors declare no competing financial interests.

\section{*L.Z. and T.C. contributed equally to this work.}

Correspondence should be addressed to either of the following: Ling Chen, Laboratory of Reproductive Medicine, Department of Physiology, Nanjing Medical University, Hanzhong Road 140, Nanjing 210029, China, E-mail: lingchen@njmu.edu.cn; or George Liu, Institute of Cardiovascular Sciences, Peking University and Key Laboratory of Cardiovascular Sciences, China Administration of Education, Beijing 100191, China, E-mail: georgeliu@bjmu.edu.cn. DOI:10.1523/JNEUROSCI.3280-15.2016

Copyright $\odot 2016$ the authors $\quad 0270-6474 / 16 / 361242-12 \$ 15.00 / 0$ 
O-acyl transferase 2 gene and CGL2 by mutation in the Berardinelli-Seip congenital lipodystrophy 2 (BSCL2) gene that encodes seipin (Magre et al., 2001; Agarwal et al., 2002). The loss of function of the seipin gene has been identified in CGL2 (Magre et al., 2001; Van Maldergem et al., 2002). Systemic seipin knockout mice (Cui et al., 2011; Chen et al., 2012; Prieur et al., 2013) and seipin knock-out rats (Ebihara et al., 2015) display a severe lipodystrophy with a dramatic loss of fat mass, severe insulin resistance, and hypertriglyceridemia.

An important clinical feature in CGL2 patients is mental retardation with delayed cognitive development and intellectual impairment (Van Maldergem et al., 2002). Rajab et al. (2003) reported that the patients with CGL2 had sensorineural deafness and delayed cognitive development. Schuster et al. (2014) have reported that CGL2 patients have mild to moderate intellectual impairment. In contrast, subjects carrying asparagine 88 to serine (N88S) or serine 90 to leucine (S90L) develop a broad spectrum of motor neuropathy (Agarwal and Garg, 2006; Guo et al., 2013) without mental retardation (Ito et al., 2008). In addition, CGL4 patients have muscular dystrophy and delayed motor milestones that are not associated with intellectual impairment (Murakami et al., 2013). We observed anxiety- and depression-like phenotypes in neuronal seipin knock-out mice (Zhou et al., 2014). Ebihara et al. (2015) have recently reported that seipin knock-out rats show the impairment of spatial working memory. However, the underlying mechanisms remain to be elucidated.

Seipin is highly expressed in the cortex, cerebellum, hippocampus, and hypothalamus (Magre et al., 2001; Wei et al., 2013). The level of hippocampal peroxisomal proliferatoractivated receptor gamma (PPAR $\gamma)$ is remarkably reduced in neuronal seipin knock-out mice (Zhou et al., 2014). PPAR $\gamma$, a class of nuclear receptors, acts as a transcription factor involved in regulating whole-body insulin sensitivity, adipocyte differentiation, lipid storage, and glucose uptake. Knock-down of seipin in 3T3-L1 cells has been reported to reduce the expression of PPAR $\gamma$ to impair adipocyte homeostasis strongly, leading to lipodystrophy (Chen et al., 2009). The defective differentiation of adipocyte by the seipin knock-down is able to be rescued by the PPAR $\gamma$ agonist pioglitazone. PPAR $\gamma$ is also expressed in the CNS (Heneka et al., 2000; Moreno et al., 2004). A potential action of PPAR $\gamma$ in the amelioration of memory deficits has been reported in various models of cognitive deficits. For example, the cognitive impairment in Tg2576 mice, an Alzheimer's disease (AD) model, is improved by treatment with the PPAR $\gamma$ agonist rosiglitazone (rosi) that enhances ERK2 activity in the hippocampus (Denner et al., 2012). Kariharan et al. (2015) have reported that the intracranial delivery of rosi in type 2 diabetic mice significantly improves spatial memory and LTP induction without improvement of peripheral insulin sensitivity. Therefore, it is of great interest to investigate the involvement of reduced hippocampal PPAR $\gamma$ in the delayed cognitive development and intellectual impairment of CGL2 patients.

In this study, systemic seipin knock-out (seipin-sKO) mice, neuronal seipin knock-out (seipin-nKO) mice and adipose seipin knock-out (seipin-aKO) mice were used to determine whether the cognitive deficits arise from the neuronal seipin deficiency or the lipodystrophy-produced peripheral metabolic disorder. In addition, we examined the influence of neuronal seipin deficiency on basal synaptic properties and frequency-dependent LTP and the function and expression of AMPA receptor (AMPAR) and NMDA receptor (NMDAR) in hippocampal CA1 regions. Furthermore, we investigated the involvement of PPAR $\gamma$ in the spatial cognitive deficits and synaptic dysfunction induced by the seipin deficiency and the underlying mechanisms. The results of this study indicate that hippocampal seipin deficiency causes downregulation of AMPA receptors, leading to LTP and spatial cognitive deficits through reduced ERK-CREB activities, which can be rescued by PPAR $\gamma$ activation.

\section{Materials and Methods}

\section{Experimental animals}

All animal handling procedures followed the guidelines for Laboratory Animal Research of the Nanjing Medical University. The use of animals was approved by the Institutional Animal Care and Use Committee of Nanjing Medical University. The mice were maintained in a constant environmental condition (temperature $23 \pm 2^{\circ} \mathrm{C}$, humidity $55 \pm 5 \%$, and 12:12 h light/dark cycle). seipin-sKO, seipin-nKO, and seipin-aKO mice were generated as described previously (Cui et al., 2011; Liu et al., 2014; Zhou et al., 2014). Briefly, seipin loxP/loxP mice were generated as described previously (Cui et al., 2011). Neuron- and adipose-specific deletion of seipin exon 3 was induced by crossing mice with the loxP seipin allele to transgenic mice expressing Cre recombinase driven by a neuron-specific or an adipocyte-specific promoter (nestin-Cre or aP2Cre; Jackson Laboratories). Progenies were screened by PCR for loss of the seipin exon 3 and presence of nestin-Cre or aP2-Cre. The genotype of seipin-nKO and seipin-aKO mice was identified by PCR using genomic DNA from their tails. When heterozygous seipin LoxP-nestin- or aP2Cre were obtained, they were further crossed with seipin loxP/loxP homozygous mice. The progenies were screened by genomic DNA PCR for seipin loxP/loxP with nestin- or aP2-Cre, which would be used in subsequent experiments. The genotype identification of seipin-sKO, seipinnKO mice, seipin-aKO mice was performed according to the procedures described in the above citations. All animals received a standard laboratory diet before and after all procedures.

In this study, 12-week-old male seipin-sKO mice $(n=24)$ and WT littermates $(n=24)$, male seipin-nKO mice $(n=128)$ and control mice $(n=128)$, male seipin-aKO mice $(n=24)$ and a-control mice $(n=24)$ were used at the beginning of all experiments. All mice were randomly assigned to different experimental groups: (1) behavioral tests $(n=12$ mice for each group) $\rightarrow$ Western blot analyses/RT-PCR $(n=8$ mice for each group, unilateral hippocampal tissue per mice was used for Western blot analyses or RT-PCR) were sequentially performed in the same cohorts; (2) electrophysiological analysis was performed in the separate cohorts ( $n=8$ mice for each group); (3) pharmacological experiments were examined in the separate cohorts ( $n=8$ mice for each group); and (4) the concentration of BDNF was measured in the difference cohorts ( $n=8$ mice for each group). Each experiment was performed by two experimenters blinded to the experimental groups.

\section{Drug administration}

The PPAR $\gamma$ agonist rosiglitazone (rosi; Enzo) was dissolved in dimethyl sulfoxide (DMSO) and then diluted in $0.9 \%$ saline to a final concentration of $0.5 \%$ DMSO. The oral administration of rosi was given daily at a dose of $5 \mathrm{mg} / \mathrm{kg}$ (Salehi-Sadaghiani et al., 2012). In addition, hippocampal slices were treated with acute perfusion of rosi $(1 \mu \mathrm{M})$ for $30 \mathrm{~min}$. The MEK inhibitor U0126 and Trk family inhibitor K252a were purchased from Sigma-Aldrich and dissolved in 0.5\% DMSO. For repeated intracerebroventricular injection of U0126 $(0.3 \mathrm{nmol} / 3 \mu \mathrm{l} /$ mouse; Yang et al., 2012) or K252a $(0.2 \mu \mathrm{m} / 3 \mu \mathrm{l} /$ mouse; Camarena et al., 2010), a $26 \mathrm{G}$ stainless-steel guide cannula (Plastics One) was implanted into the right lateral ventricle $(0.3 \mathrm{~mm}$ posterior to bregma, $1.0 \mathrm{~mm}$ lateral, and 2.3 $\mathrm{mm}$ ventral) and anchored to the skull with 3 stainless steel screws and dental cement.

\section{Behavioral examination}

Morris water maze task. The apparatus of the Morris water maze was a pool (diameter $=120 \mathrm{~cm}$ ) made of white-colored plastic. Milk powder was used to render the water opaque. The apparatus was housed in a light-controlled room and maintained at a temperature of $20 \pm 1^{\circ} \mathrm{C}$. The pool was divided arbitrarily into four equally sized quadrants. The walls around the pool were pasted with high contrast visual cues (an X, a triangle, a circle, and a square) to allow animals to build up their spatial 
memory (Tsai et al., 2011). Swimming paths were analyzed by a computer system with a video camera (AXIS-90 Target/2; Beijing Sunny Instruments). On days 1-2 of training, a cylindrical dark-colored platform ( $7 \mathrm{~cm}$ in diameter) was placed $0.5 \mathrm{~cm}$ above the surface of the water. On days 3-7 of training, the platform was moved to the opposite quadrant of the visible platform and submerged $1 \mathrm{~cm}$ below the water surface. Three starting positions were used pseudorandomly. The escape latency to reach the visible platform or the hidden platform and swim distance were measured. If the mouse could not reach the platform within $90 \mathrm{~s}$, the experimenter gently assisted it onto the platform and allowed it to remain there for $10 \mathrm{~s}$. The mouse was then dried and returned to the cage to rest for $15 \mathrm{~min}$ before the next trial. After removing the platform, the probe trial was performed on day 8 of training. The mouse was released from the opposite quadrant of a hidden platform to allow swimming for $90 \mathrm{~s}$ to determine its search patterns. The percentage of total time spent in each quadrant was measured.

$Y$-maze task. Spatial working memory performance was assessed by recording spontaneous alternation behavior in a Y-maze (Maurice et al., 1996). Y-maze task was performed at $48 \mathrm{~h}$ after the probe trial task. Y-maze was made of black painted wood. Each arm was $40 \mathrm{~cm}$ long, 13 $\mathrm{cm}$ high, $3 \mathrm{~cm}$ wide at the bottom, $10 \mathrm{~cm}$ wide at the top, and converged at an equal angle. Each mouse was placed at the end of one arm and allowed to move freely through the maze during an $8 \mathrm{~min}$ session. The series of arm entries was recorded visually and arm entry was considered to be completed when the hindpaws of the mouse were completely placed in the arm. Alternation was defined as successive entries into the three arms on overlapping triplet sets. The percentage alternation was calculated as the ratio of actual to possible alternations (defined as the total number of arm entries minus two). The scorers were blinded to the treatment groups.

\section{Histological examination}

The mice were anesthetized with chloral hydrate $(400 \mathrm{mg} / \mathrm{kg}$, i.p.) and perfused transcardially with $4 \%$ paraformaldehyde. Brains were removed and processed for paraffin embedding. Coronal sections ( $5 \mu \mathrm{m}$ in thickness) were placed in gelatin-coated slides, blocked with 3\% normal goat serum, and then incubated in rabbit monoclonal anti-seipin antibody (1:1000) at $4^{\circ} \mathrm{C}$ overnight (Jiang et al., 2014). The seipin monoclonal antibody was a kind gift from Professor Jiahao Sha (State Key Laboratory of Reproductive Medicine, Nanjing Medical University, China). After PBS rinses, the sections were incubated in biotin-labeled goat anti-rabbit IgG antibody (1:500; Bioworld Technology) for $2 \mathrm{~h}$. Immunoreactivities were visualized by avidin-biotin horseradish peroxidase complex (ABC Elite; Vector Laboratories) using 3,3' -diaminobenzidine as the chromogen. The immunopositive cells/fibers were observed using a conventional light microscope (40× objective, DP70; Olympus).

\section{Electrophysiological analysis}

The mice were deeply anesthetized with isofluorane and decapitated. The brains were rapidly removed and coronal brain slices $(400 \mu \mathrm{m})$ were cut using a vibrating microtome (Microslicer DTK 1500; Dousaka) in icecold cutting solution composed of the following (in mM): 94 sucrose, 30 $\mathrm{NaCl}, 4.5 \mathrm{KCl}, 1.0 \mathrm{MgCl}_{2}, 26 \mathrm{NaHCO}_{3}, 1.2 \mathrm{NaH}_{2} \mathrm{PO}_{4}$, and 10 D-glucose, $\mathrm{pH}$ 7.4. The hippocampal slices were continuously perfused with artificial CSF (ACSF) at $30 \pm 1^{\circ} \mathrm{C}$ for $>60 \mathrm{~min}$ to recover from damage. ACSF was composed of the following (in mM): $124 \mathrm{NaCl}, 2 \mathrm{CaCl}_{2}, 4.5 \mathrm{KCl}, 1$ $\mathrm{MgCl}_{2}, 26 \mathrm{NaHCO}_{3}, 1.2 \mathrm{NaH}_{2} \mathrm{PO}_{4}$, and 10 D-glucose, with the $\mathrm{pH}$ was adjusted to 7.4. Both the cutting solution and ACSF were oxygenated with a gas mixture of $95 \% \mathrm{O}_{2} / 5 \% \mathrm{CO}_{2}$.

Field potential recording. After a slice was submerged in a recording chamber, one of two hydraulic micromanipulators (MMW204; Narishige) mounted on the microscopic stage were used to place a bipolar tungsten stimulating electrode in Schaffer collateral. EPSP was recorded from the radium layer with a $5 \mathrm{M} \Omega$ resistance glass microelectrode that was filled with $2 \mathrm{M} \mathrm{NaCl}$ and connected to a preamplifier with a high-pass filter at $5 \mathrm{kHz}$. Signals were amplified by a differential AC amplifier (A-M Systems, model 1700). The EPSPs were digitized and saved using a pCLAMP system (Axon). Generally, the test stimulus was set at $\sim 50 \%$ of maximum stimulus intensity that evoked a saturated EPSP in each slice.
First, input/output function was assessed by averaging the stimulus intensity from 0.1 to $1.5 \mathrm{~mA}$. Second, paired-pulse facilitation (PPF) was measured by two stimuli with an interpulse interval (IPI) of 25-100 ms. Paired-pulse ratio (PPR) was calculated with the following formula: $\left(\mathrm{EPSP}_{\mathrm{S} 2} / \mathrm{EPSP}_{\mathrm{S} 1}\right) \times 100$, where $\mathrm{EPSP}_{\mathrm{S} 1}$ and $\mathrm{EPSP}_{\mathrm{S} 2}$ represent EPSP slopes to the first and second stimulation, respectively. Third, LTP was induced by conditioning stimulations. After delivering conditioning stimulations, the EPSP slopes were recorded for a further period of 60 min. LTP was determined 55-60 min after delivering conditioning stimulations if the EPSP slopes were larger than $20 \%$ of baseline.

Patch-clamp recording. Experiments were performed at $32-34^{\circ} \mathrm{C}$, with the temperature maintained by an in-line heating device (Warner Instruments). AMPA-activated current $\left(I_{\mathrm{AMPA}}\right)$ in hippocampal CA1 pyramidal cells was induced by the application of AMPA (Li et al., 2013b) using a rapid drug delivery system and recorded using an EPC-10 amplifier (HEKA Elektronik). The holding potential was $-60 \mathrm{mV}$ and the glass pipette resistance was $4-5 \mathrm{M} \Omega$ filled with an internal solution containing the following (in mu): $\mathrm{CsCl} 140, \mathrm{MgCl}_{2} 2, \mathrm{CaCl}_{2}$ 1, Tris-ATP 2, HEPES 10, and EGTA 10, pH 7.2. The hippocampal pyramidal neuron was perfused with oxygenated ACFS containing $10 \mu \mathrm{M}$ D-APV, $1 \mu \mathrm{M}$ strychnine, $10 \mu \mathrm{M}$ bicuculline, and $0.1 \mu \mathrm{M}$ TTX. In the dose-response curve, $I_{\mathrm{AMPA}}$ induced by various doses $(1-300 \mu \mathrm{M})$ of AMPA was normalized to $I_{\mathrm{AMPA}}$ induced by $300 \mu \mathrm{M}$ AMPA in the same neuron. The data were fitted to a logistic equation in which $I=I_{\max } /\left[1+\left(\mathrm{EC}_{50} / C\right) n\right]$, with $n$ being the Hill coefficient and $\mathrm{EC}_{50}$ being the concentration producing $50 \%$ maximal response.

NMDA-activated current $\left(I_{\mathrm{NMDA}}\right)$ was induced as described previously (Li et al., 2013a). The slices were perfused continually with the oxygenated calcium-free ACFS. Ten micromolar bicuculline, $10 \mu \mathrm{M}$ NBQX, and $0.1 \mu \mathrm{M}$ TTX were applied extracellularly. In the doseresponse curve, $I_{\mathrm{NMDA}}$ induced by various doses (1-1000 $\left.\mu \mathrm{M}\right)$ of NMDA was normalized to $I_{\mathrm{NMDA}}$ induced by $1000 \mu \mathrm{M}$ NMDA in the same neuron.

\section{Western blot analyses}

Tissues obtained from the hippocampus were homogenized in $1 \%$ Nonidet P-40 lysis buffer containing $50 \mathrm{~mm}$ Tris, $150 \mathrm{~mm} \mathrm{NaCl}, 0.02 \% \mathrm{NaN}_{3}$, and complete protease inhibitors (Roche). The homogenates were centrifuged for $15 \mathrm{~min}$ at 12,000 r.p.m. (Thermo Scientific) and the supernatants were collected. Proteins $(50 \mu \mathrm{g})$ were loaded in each lane for separation in SDS-PAGE and transferred to nitrocellulose membranes. Blotting membranes were incubated with blocking solution (5\% nonfat dried milk) for $1 \mathrm{~h}$ at room temperature, washed three times, and then incubated with rabbit monoclonal antibodies of phosphorylation ERK1/2 or CREB (1:1000; Cell Signaling Technology), rabbit monoclonal antibodies of GluR1, GluR2, or PPAR $\gamma$ (1:1000; Cell Signaling Technology) at $4^{\circ} \mathrm{C}$ overnight. After being washed with TBST, the membranes were incubated for $1 \mathrm{~h}$ with HRP-labeled secondary antibodies and developed using the ECL detection kit (GE Healthcare). After visualization, the blots were stripped by incubation in a stripping buffer (Restore; Pierce) for $5 \mathrm{~min}$, reblocked with $5 \%$ nonfat dried milk at room temperature for $60 \mathrm{~min}$, and then incubated with rabbit monoclonal antibodies of ERK1/2 or CREB (1:1000; Cell Signaling Technology). Internal control was performed using a GAPDH antibody (1:5000; Bioworld Technology) or $\beta$-actin antibody (1:2000; Cell Signaling Technology). Western blot bands were scanned and analyzed with ImageJ.

\section{$R T-P C R$}

Real-time PCR was performed as described previously (Wang et al., 2009). Total RNA was isolated from the hippocampus using TRIzol reagent (Invitrogen) and reverse-transcribed into cDNA using a PrimeScript RT reagent kit (Takara) for quantitative PCR (ABI Step One Plus) in the presence of a fluorescent dye (SYBR Green I; Takara). The relative expression of genes was determined using the $2-\Delta \Delta$ ct method with normalization to GAPDH expression. Primer sets were used as listed in Table 1.

\section{Data analysis/statistics}

The data were retrieved and processed with the software PulseFit (HEKA Elektronik) and Microcal Origin 6.1. The group data are expressed as the 
Table 1. Primer sequences for RT-PCR

\begin{tabular}{|c|c|c|}
\hline Gene & Sense primer & Antisense primer \\
\hline GluR1 & 5'-TTGCCTTAATCGAGTTCTGCTAC-3' & 5'-GTATGGCTTCATTGATGGATTG-3' \\
\hline GluR2 & $5^{\prime}-C C A G G G A T G C A G A C A C C A A A-3^{\prime}$ & 5'-GGCTCATGAATGGCTTCGAGA-3' \\
\hline NR1 & $5^{\prime}$-TCACCTCCACCCTGGCCTCC-3' & 5'-GCTGGCCCTCCTCCCTCTCA-3' \\
\hline NR2A & $5^{\prime}$-ATCATGGCTGACAAGGATCCGACA-3' & $5^{\prime}$-TGACCAAGGAGAAGACATGCCAGT-3' \\
\hline NR2B & $5^{\prime}$-CTGCATGCGGAATACAGTC-3' & 5'-TTGATGTAGCCTGGTTCCT-3' \\
\hline PSD 95 & 5'-GGTGACGACCCATCCATCTTTATC-3' & $5^{\prime}$-CGGACATCCACTTCATTGACAAAC-3' \\
\hline TARPs $(\gamma-8)$ & 5'-GGGGGCAGTGGCTCCTCAGA-3' & $5^{\prime}-$ CAGGCCTGCTGCCACGAACA-3' \\
\hline FAS & 5'-GGGTCTATGCCACGATTC-3' & 5'-GTGTCCCATGTTGGATTTG-3' \\
\hline GAPDH & $5^{\prime}$-TGGGTGTGAACCACGAG-3' & $5^{\prime}$-ACCACAGTCCATGCCATCAC-3' \\
\hline
\end{tabular}

means \pm SEM. The difference between the two groups was evaluated using Student's $t$ test. In analyzing one-variable experiments with $>2$ groups, the significance of the difference was evaluated using ANOVA followed by Bonferroni's post hoc tests. Statistical analysis was performed using Stata 7 software (STATA). Differences at $p<0.05$ were considered statistically significant.

\section{Results}

Neuronal seipin deficiency reduces hippocampal PPAR $\gamma$ level Consistent with the previous reports (Magre et al., 2001; Ebihara et al., 2015), the seipin was highly expressed in hippocampal CA1 pyramidal cells of mice (Fig. 1A). Compared with WT mice or control mice, the levels of hippocampal PPAR $\gamma$ protein in seipinsKO mice $\left(F_{(1,28)}=32.179, p<0.001\right.$; Fig. $\left.1 B\right)$ and seipin-nKO mice $\left(F_{(1,28)}=20.094, p<0.001\right)$ were significantly reduced and were not affected by the treatment with the PPAR $\gamma$ agonist rosi (5 $\mathrm{mg} / \mathrm{kg}$, p.o.) for $3 \mathrm{~d}$ (seipin-sKO: $F_{(1,28)}=0.227, p=0.637$; seipinnKO: $\left.F_{(1,28)}=0.400, p=0.532\right)$. In contrast, the PPAR $\gamma$ protein level in seipin-aKO mice had no significant difference from a-control mice $\left(F_{(1,28)}=0.165, p=0.688\right)$. In addition, rosi treatment in WT mice, control mice, or a-control mice failed to alter the level of hippocampal PPAR $\gamma(p>0.05, n=8)$.

\section{Rosi improves seipin-deficiency-induced spatial cognitive deficits}

Spatial memory was examined using place learning in the Morris water maze task. The mean latency to find visible platform on days 1-2 of training and the subsequent escape latency to reach hidden platform on days 3-7 of training were recorded in seipinsKO mice and WT mice (Fig. 2A), seipin-nKO mice and control mice (Fig. $2 \mathrm{C}$ ), or in seipin-aKO mice and a-control mice (Fig. $2 E)$, respectively. To test the influence of reduced $\operatorname{PPAR} \gamma$ by the seipin deficiency on spatial memory, rosi treatment $(5 \mathrm{mg} / \mathrm{kg}$, p.o.) was given starting $3 \mathrm{~d}$ before the behavioral examinations for $12 \mathrm{~d}$. First, the latency of visible platform was not affected by the genotypes (seipin-sKO: $F_{(1,44)}=0.016, P=0.961$; seipin-nKO: $F_{(1,44)}=0.225, p=0.637$; seipin-aKO: $\left.F_{(1,44)}=0.046, p=0.831\right)$ or rosi treatment (seipin-sKO: $F_{(1,44)}=0.010, p=0.922$; seipinnKO: $F_{(1,44)}=0.001, p=0.978$; seipin-aKO: $F_{(1,44)}=0.058, p=$ 0.810). Repeated-measures ANOVA revealed that the escape latency of the hidden platform progressively decreased with training days in all groups (seipin-sKO: $F_{(4,176)}=64.284, p<$ 0.001; seipin-nKO: $F_{(4,176)}=84.587, p<0.001$; seipin-aKO: $\left.F_{(4,176)}=90.982, p<0.001\right)$. There was a main effect of genotype for the escape latency in seipin-sKO mice $\left(F_{(1,44)}=7.398, p=\right.$ $0.009)$ and seipin-nKO mice $\left(F_{(1,44)}=11.026, p=0.002\right)$, but not in seipin-aKO mice $\left(F_{(1,44)}=0.084, p=0.774\right)$. Another main effect was rosi treatment (seipin-sKO: $F_{(1,44)}=7.55, p=0.009$; seipin-nKO: $\left.F_{(1,44)}=10.021, p=0.003\right)$. Compared with controls, seipin-sKO mice ( $p=0.027)$ and seipin-nKO mice ( $p=$ 0.004 ) needed a longer time to reach the hidden platform on day
5-7 of training, which were improved by rosi treatment (seipinsKO: $p=0.036$; seipin-nKO: $p=0.009$ ). The swimming speed during visible and hidden platform tests was not affected by the genotypes (seipin-sKO: $F_{(1,44)}=0.080, p=0.928$; seipin-nKO: $F_{(1,44)}=0.067, p=0.798$; seipin-aKO: $\left.F_{(1,44)}=0.042, p=0.839\right)$ or rosi treatment (seipin-sKO: $F_{(1,44)}=0.104, p=0.749$; seipinnKO: $F_{(1,44)}=0.029, p=0.866$; seipin-aKO: $F_{(1,44)}=0.031, p=$ $0.861)$.

A probe test was conducted $24 \mathrm{~h}$ after the hidden platform training. The swimming times spent in each quadrant (platform, opposite, and adjacent two quadrants) are shown in Figure 2, B, $D$, and $F$, respectively. There was a main effect of genotype for the swimming times of platform quadrant in seipin-sKO mice $\left(F_{(1,44)}\right.$ $=11.926, p=0.001)$ or seipin-nKO mice $\left(F_{(1,44)}=8.799, p=\right.$ $0.005)$, but not in seipin-aKO mice $\left(F_{(1,44)}=1.310, p=0.259\right)$. In addition, there was a main effect of rosi treatment (seipin-sKO: $F_{(1,44)}=7.347, p=0.01$; seipin-nKO: $\left.F_{(1,44)}=9.794, p=0.03\right)$. The seipin-sKO mice $(p=0.001)$ and seipin-nKO mice $(p<$ 0.001 ) spent less swimming time in the platform quadrant than WT mice and control mice. rosi treatment in seipin-sKO mice $(p=0.002)$ and seipin-nKO mice $(p<0.001)$ increased swimming time in the platform quadrant.

Spatial working memory was evaluated by Y-maze test $48 \mathrm{~h}$ after the probe trial task. The alternation ratio and number of arm entries are shown in Figure 2, $G$ and $H$. There was a main effect of genotype for alternation ratio in seipin-sKO mice $\left(F_{(1,44)}=\right.$ 11.926, $p=0.001)$ or seipin-nKO mice $\left(F_{(1,44)}=8.799, p=\right.$ $0.005)$, but not in seipin-aKO mice $\left(F_{(1,44)}=0.335, p=0.566\right)$. In addition, rosi treatment was a main effect for the alternation ratio (seipin-sKO: $F_{(1,44)}=7.565, p=0.009$; seipin-nKO: $F_{(1,44)}=$ $5.933, p=0.018)$. The alternation ratio in seipin-sKO mice ( $p=$ $0.001)$ or seipin-nKO mice $(p<0.001)$ was reduced compared with WT mice or control mice, which was rescued by rosi treatment (seipin-sKO: $p<0.001$; seipin-nKO: $p<0.001$ ). In contrast, the number of arm entries was not altered by the genotypes (seipin-sKO: $F_{(1,44)}=0.071, p=0.792$; seipin-nKO: $F_{(1,44)}=0.234$, $p=0.631$; seipin-aKO: $\left.F_{(1,44)}=0.035, p=0.853\right)$ or rosi treatment (seipin-sKO: $F_{(1,44)}=0.196, p=0.660$; seipin-nKO: $F_{(1,44)}=0.107, p=0.745 ;$ seipin-aKO: $\left.F_{(1,44)}=0.096, p=0.758\right)$.

\section{Rosi rescues seipin-deficiency-impaired hippocampal synaptic function and LTP}

To explore the mechanisms underlying the neuronal seipindeficiency-impaired spatial memory, the basal property of Schaffer collateral-CA1 synaptic transmission was analyzed by plotting fractional changes in EPSP slopes against diverse stimulating intensities (0.2-1.5 mA). The repeated-measures ANOVA revealed a main effect of seipin-nKO $\left(F_{(1,36)}=10.709, p=0.002\right.$; Fig. $3 A$ ). In addition, there was a main effect of rosi treatment $\left(F_{(1,36)}=4.406, p=0.043\right)$. The input-output curve revealed that the EPSP slopes elicited by the test stimulus at $0.6-1.5 \mathrm{~mA}$ were less in seipin-nKO mice than those in control mice $(p=$ 0.002 ), which could be corrected by rosi treatment for $3 \mathrm{~d}$ ( $p=$ 0.043 ). The PPF with an IPI ranging from 25 to $150 \mathrm{~ms}$ was measured to analyze the capability of presynaptic glutamate release. PPRs in seipin-nKO mice were not significantly different from those in control mice $\left(F_{(1,36)}=0.113, p=0.738\right.$; in Fig. $3 B)$ and were not affected by rosi treatment $\left(F_{(1,36)}=\right.$ $1.007, p=0.322$ ).

The induction of Schaffer collateral-CA1 synaptic LTP was further examined by delivering a conditioning stimulation. As shown in Figure $3 C$, the high-frequency conditioning stimulation ( 100 pulses at $100 \mathrm{~Hz}$ ) could induce $\sim 40 \%$ increase of EPSP 
slopes lasting over $60 \mathrm{~min}$, indicative of "LTP", in the slices obtained from control mice $(n=8)$, but not from seipin-nKO mice $(n=8)$. The frequency-dependent LTP induction in control mice was blocked by the NMDAR antagonist MK801 ( $n=8$; Fig. 3D). Interestingly, the same protocol was able to induce a stable LTP in seipin-nKO mice treated with rosi for $3 \mathrm{~d}(n=8$; Fig. $3 E)$. In contrast, acute treatment with rosi $(1 \mu \mathrm{M})$ for $30 \mathrm{~min}$ in the slices obtained from seipin-nKO mice failed to rescue the induction of LTP $(n=$ 8; Fig. $3 F$ ).

Rosi recovers seipin deficiency-reduced AMPAR expression and activity

The next experiment was designed to examine the function and expression of AMPAR and NMDAR in hippocampal CA1 pyramidal cells using whole-cell patch-clamp recording, RT-PCR, and Western blot analysis. Typical recordings of $I_{\mathrm{AMPA}}(100-300 \mu \mathrm{M})$ and $I_{\mathrm{NMDA}}(1-$ $1000 \mu \mathrm{M})$ are shown in Figure $4, A$ and $B$. The densities of $I_{\mathrm{AMPA}}$ in seipin-nKO mice were less than those in control mice $\left(F_{(1,18)}=28.999, p<0.001\right)$. However, there was no difference between the $\mathrm{EC}_{50}$ of the dose-response curve of $I_{\mathrm{AMPA}}$ in seipin-nKO mice $(30 \pm 2.78 \mu \mathrm{M})$ and control mice $(33 \pm 3.52 \mu \mathrm{M} ; p=0.539)$. In contrast, the densities of $I_{\mathrm{NMDA}}$ were not altered in seipin-nKO mice compared with control mice $\left(F_{(1,18)}=0.807, p=\right.$ $0.381)$. rosi treatment for $3 \mathrm{~d}$ could correct the reduction of $I_{\mathrm{AMPA}}$ in seipin-nKO mice (vs control $p=$ $0.370, n=10$; Fig. $4 C)$, but failed to affect the $I_{\mathrm{NMDA}}(p=0.727$, $n=10)$. In addition, acute treatment with rosi $(1 \mu \mathrm{M})$ for $30 \mathrm{~min}$ in the slices obtained from seipin-nKO mice had no effect on the $I_{\mathrm{AMPA}}(p=0.002, n=10$; Fig. $4 D)$ or $I_{\mathrm{NMDA}}(p=0.711, n=10)$.

Levels of hippocampal GluR1/2 mRNA and GluR1/2 protein are shown in Figure 4, $E$ and $F$. There was a main effect of seipin$\mathrm{nKO}$ for the GluR1 $\left(F_{(1,35)}=8.014, p=0.008\right)$ and GluR2 mRNAs $\left(F_{(1,35)}=24.068, p<0.001\right)$ and the GluR1 $\left(F_{(1,35)}=4.474\right.$, $p=0.042)$ and GluR2 proteins $\left(F_{(1,35)}=4.549, p=0.040\right)$. Another main effect was rosi treatment for the GluR1 $\left(F_{(1,35)}=\right.$ 10.886, $p=0.002)$ and GluR2 mRNAs $\left(F_{(1,35)}=22.021, p<\right.$ $0.001)$ or GluR1 $\left(F_{(1,35)}=10.694, p=0.002\right)$ and GluR2 proteins $\left(F_{(1,35)}=18.011, p<0.001\right)$. Compared with controls, the levels of GluR1/2 mRNA $(p<0.001)$ and GluR1/2 protein $(p<0.001)$ in seipin-nKO mice were significantly reduced, which could be corrected by rosi treatment for $3 \mathrm{~d}$ (GluR1/2 mRNA: $p<0.001$; GluR1/2 protein: $p<0.001)$. In contrast, acute treatment with rosi $(1 \mu \mathrm{M})$ for $30 \mathrm{~min}$ in the slices obtained from seipin-nKO mice could not increase the levels of GluR1 ( $p=0.489, n=8)$ and GluR2 proteins ( $p=0.472, n=8)$, although it partially corrected the reduction of GluR1 ( $p=0.049, n=8)$ and GluR2 mRNAs $(p=0.032, n=8)$. In addition, the levels of $N R 1\left(F_{(1,28)}\right.$ $=0.130, p=0.721), N R 2 A\left(F_{(1,28)}=0.440, p=0.512\right)$, and NR2B mRNAs $\left(F_{(1,28)}=0.269, p=0.608\right)$ in seipin-nKO mice did not differ significantly from control mice. The results indicate that the seipin deficiency suppresses AMPAR expression, leading control mice

CA1

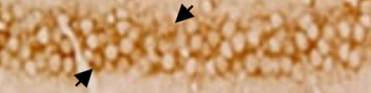

(n)

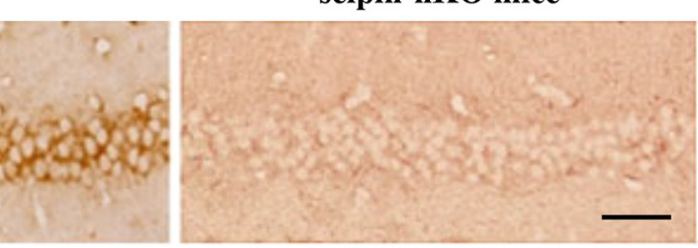

seipin-nKO mice

B

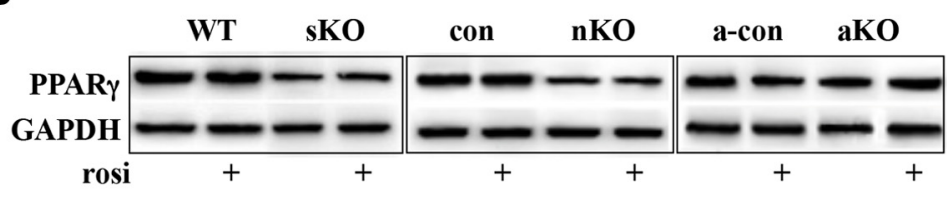

\section{control} seipin-sKO
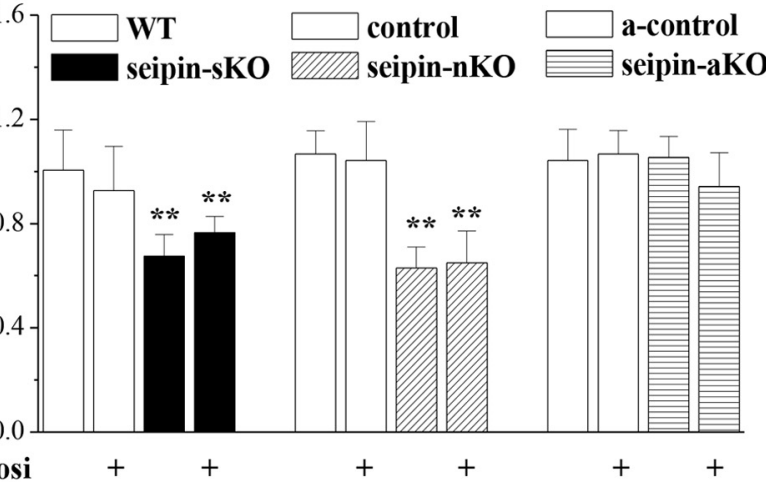

Figure 1. Neuronal seipin deficiency reduces hippocampal PPAR $\gamma$ level. $A$, Representative images of seipin immunostaining in hippocampal CA1 region of control mice and seipin-nK0 mice. str-R, Stratum radiatum; str-P, stratum pyramidale; str-0, stratum . Arrows indicate seipin-immunopositive cells. Scale bars, $50 \mu \mathrm{m} . \boldsymbol{B}$, Bars show the levels of hippocampal PPAR $\gamma$ in seipinT mice, seipin-nKO mice and control mice, or seipin-aKO mice and a-control mice treated with vehicle or rosi for $3 \mathrm{~d}$ The densitometric values for Western blots of protein are normalized to the amounts of GAPDH and normalized again by control values. ${ }^{* *} p<0.01$ versus WT mice or control mice (two-way ANOVA).

to a reduction of $I_{\mathrm{AMPA}}$, which could be restored by activation of $\operatorname{PPAR} \gamma$.

\section{Rosi rescues seipin-deficiency-reduced ERK-CREB phosphorylation}

The levels of hippocampal phosphorylation of ERK2 (phosphorERK2) and cAMP response element binding protein (phosphorCREB) are illustrated in Figure 5, $A$ and $B$, respectively. There was a main effect of seipin-nKO for the phosphor-ERK2 $\left(F_{(1,42)}=\right.$ 30.129, $p<0.001)$ and phosphor-CREB $\left(F_{(1,56)}=15.752, p<\right.$ $0.001)$. Another main effect was rosi treatment for the phosphor$\operatorname{ERK} 2\left(F_{(1,42)}=22.367, p<0.001\right)$ and phosphor-CREB $\left(F_{(1,56)}\right.$ $=18.865, p<0.001)$. The decline of phosphor-ERK2 and phosphor-CREB $(p<0.001)$ in seipin-nKO mice was corrected by rosi treatment for $3 \mathrm{~d}(p<0.001)$. The MEK inhibitor U0126 could block the rosi-corrected phosphor-CREB in seipin-nKO mice $(p<0.001, n=8)$ and attenuate the basal level of phosphor-CREB in control mice $(p<0.001, n=8)$. In contrast, there was no significant main effect of seipin-nKO $\left(F_{(1,28)}=\right.$ $0.180, p=0.675$; Fig. $5 C)$ for the hippocampal mature BDNF. However, there was a main effect of rosi treatment $\left(F_{(1,28)}=\right.$ $10.749, p=0.003)$. The concentration of mature BDNF was increased by rosi treatment for $3 \mathrm{~d}$ in control mice $(p=0.025, n=$ 8 ) or seipin-nKO mice ( $p=0.047, n=8)$. However, inhibition of TrkB receptor by $\mathrm{K} 252 \mathrm{a}$ in seipin-nKO mice did not affect the rosi-corrected phosphor-ERK2 $(p=0.578)$ and phosphorCREB $(p=0.666)$. 

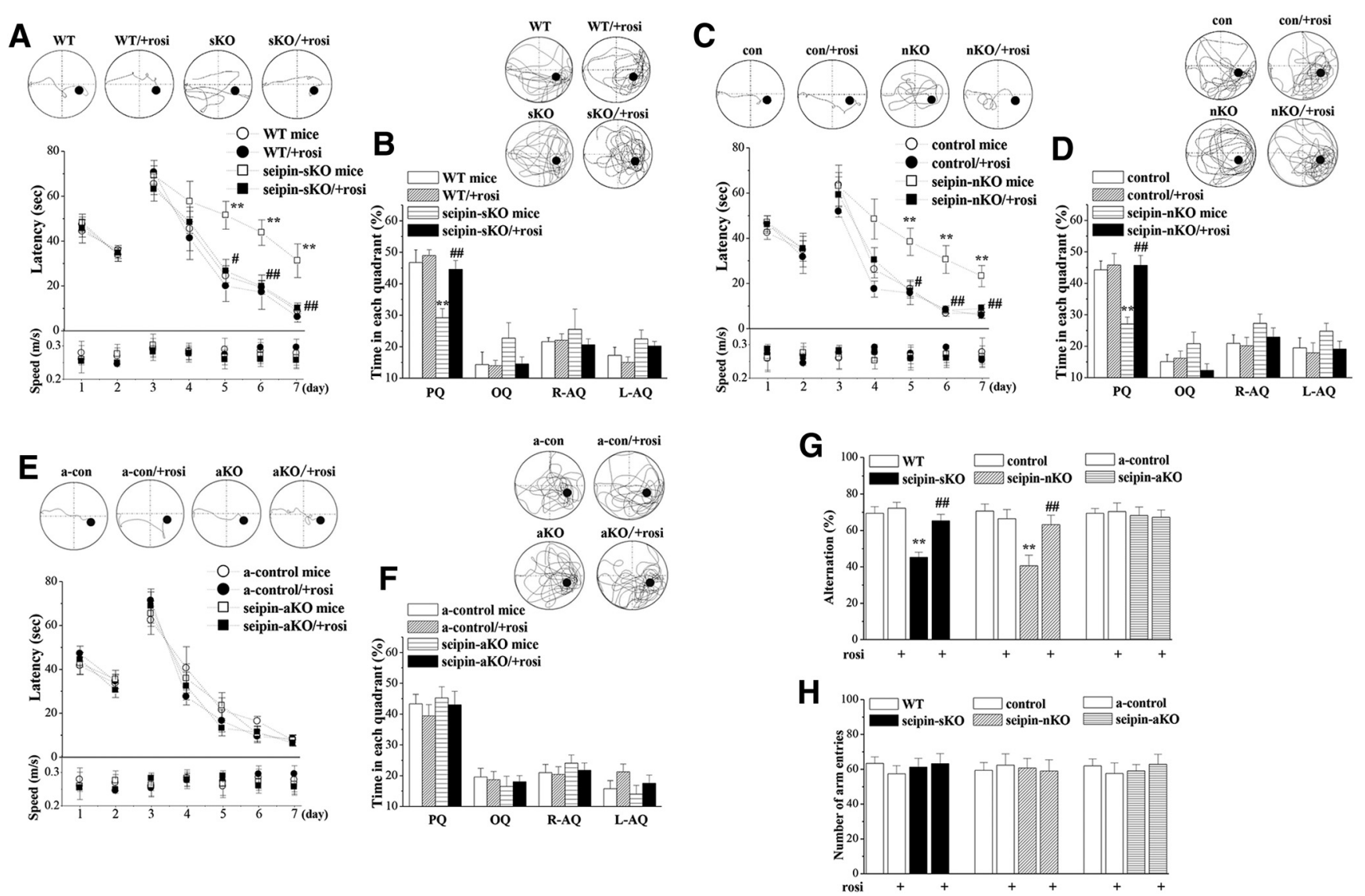

Figure 2. Treatment with rosi improves neuronal seipin-deficiency-induced spatial cognitive deficits. In the Morris water maze test, latency (in seconds) to reach visible and hidden platform ( $\boldsymbol{A}$, $\boldsymbol{C}, \boldsymbol{E})$ and percentage of swimming time $(\boldsymbol{B}, \boldsymbol{D}, \boldsymbol{F})$ in 4 quadrants $(\%)$ of platform $(\mathrm{PQ})$, opposite $(0 Q)$, and right/left adjacent $(\mathrm{R}-\mathrm{AQ}, \mathrm{L}-\mathrm{AQ})$ in seipin-sKO mice and WT mice $(\boldsymbol{A}, \boldsymbol{B})$, seipin-nK0 mice and control mice $(\boldsymbol{C}, \boldsymbol{D})$, or seipin-aKO mice and a-control mice $(\boldsymbol{E}, \boldsymbol{F})$. Tracings of typical swimming patterns on day 7 of hidden platform trainings and probe test are shown at the top. Black circles indicate the position of the platform. $\boldsymbol{A}_{,}{ }^{* *} p<0.01$ versus WT mice; \#p $<0.05$, \#\#p $<0.01$ versus seipin-sKO mice (repeated-measure ANOVA). ${ }^{,},{ }^{* *} p<0.01$ versus WT mice; \#\#p $<0.01$ versus seipin-sKO mice (two-way ANOVA). $C^{* *} p<0.01$ versus control mice; $\# p<0.05$, \#\#p $<0.01$ versus seipin-nKO mice (repeated-measure ANOVA). $\boldsymbol{D},{ }^{* *} p<0.01$ versus control mice; \#\#p $<0.01$ versus seipin-nKO mice (two-way ANOVA). $\mathbf{G}, \boldsymbol{H}$, Alternation ratio (\%) and total arm entries in Y-maze. ${ }^{* *} p<0.01$ versus WT mice or control mice; \#\#p $<0.01$ versus seipin-sKO mice or seipin-nK0 mice (two-way ANOVA).

\section{Seipin-deficiency-reduced ERK-CREB signaling impairs AMPAR expression and LTP}

To determine whether the rosi-recovered ERK-CREB activity or increased BDNF is required for rosi-rescued AMPAR expression and LTP induction, seipin-nKO mice were treated with intracerebroventricular injection of U0126 or K252a at 30 min before rosi administration (Fig. $6 \mathrm{~A}$ ). The results showed that the administration of U0126 in seipin-nKO mice could block the rosiincreased GluR1 ( $p<0.001, n=8$; Fig. 6B) and GluR2 mRNAs $(p<0.001, n=8)$ or the rosi-restored $I_{\mathrm{AMPA}}(p=0.019, n=8$; Fig. $6 C)$ and LTP $(n=8$; Fig. $6 D)$. In addition, the administration of U0126 in control mice attenuated the levels of GluR1 $(p<$ $0.001, n=8)$ and GluR2 mRNAs $(p=0.001, n=8)$ and the $I_{\mathrm{AMPA}}(p=0.001, n=8)$, which were insensitive to rosi treatment. The administration of K252a in seipin-nKO mice failed to affect the rosi-increased GluR1 $(p=0.476, n=8)$ and GluR2 mRNAs $(p=0.330, n=8)$ or the rosi-restored $I_{\mathrm{AMPA}}(p=0.932$, $n=8)$.

\section{Discussion}

The present study provides in vivo evidence that neuronal seipin deficiency leads to spatial cognitive deficits thtat can be rescued by the activation of PPAR $\gamma$. This conclusion is deduced mainly from the following observations. First, the seipin-sKO mice and seipin-nKO mice exhibited spatial cognitive deficits, but the
seipin-aKO mice did not. Because seipin-sKO mice and seipinaKO mice show insulin resistance and hypertriglyceridemia (Cui et al., 2011; Liu et al., 2014), the cognitive deterioration is unlikely to be secondary to the peripheral metabolic abnormalities. Second, the impairment of motor neuron by gain-of-function mutation in the $N$-glycosylation site of seipin (Ito and Suzuki, 2009) is not observed in CGL2 patients, seipin knock-out rats (Ebihara et al., 2015), or seipin-nKO mice (Zhou et al., 2014). No changes in the swim speed in Morris water maze or the number of arm entries in Y-maze were detected in seipin-sKO mice or seipinnKO mice, indicating that seipin deficiency does not affect the motor ability. Third, seipin-sKO mice and seipin-nKO mice have been reported to display a depression-like phenotype (Zhou et al., 2014). The impairment of spatial working memory as assessed by Y-maze was observed in seipin-sKO and seipin-nKO mice and seipin knock-out rats (Ebihara et al., 2015). Fourth, the hippocampal NMDAR-dependent LTP, a cellular model for spatial learning and memory (Takeuchi et al., 2014), was impaired in seipin-nKO mice. Finally, Seipin was highly expressed in hippocampal CA1 pyramidal cells. Consistent with the report by Zhou et al. (2014), the levels of hippocampal PPAR $\gamma$ were remarkably reduced in seipin-sKO mice and seipin-nKO mice, but not in seipin-aKO mice. Importantly, rosi treatment could rescue the spatial memory and the LTP induction in seipin-sKO mice 

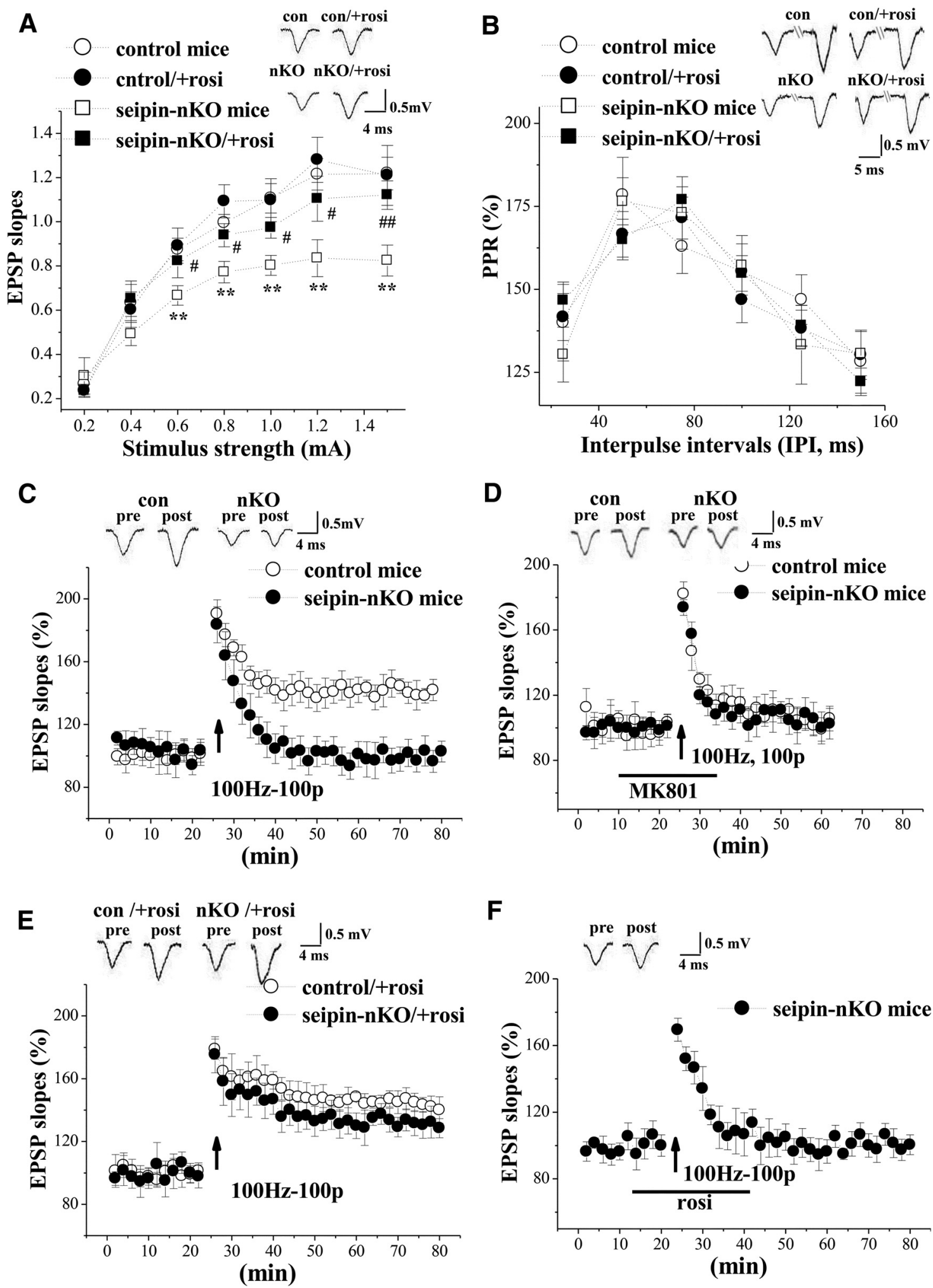

Figure 3. Treatment with rosi rescues seipin-deficiency-impaired hippocampal synaptic function and LTP. A, Input- output curve at Schaffer collateral-CA1 synapses. EPSP slopes are plotted against stimulus intensity $(0.2-1.5 \mathrm{~mA}) .{ }^{* *} p<0.01$ versus control mice; $\# p<0.05$, \#\#p $<0.01$ versus seipin-nK0 mice (repeated-measures ANOVA). Representative traces evoked by a testing stimulation (0.6 mA). B, PPR of EPSP slopes is plotted against various IPIs ranging from 25 to $150 \mathrm{~ms}$ in control mice and seipin-nKO mice treated with rosi or vehicle. Representative traces evoked with IPI of $50 \mathrm{~ms}$. C, Induction of LTP by HFS ( $100 \mathrm{~Hz}, 100$ pulses). Each point represents the group mean of EPSP slopes expressed as a percentage of baseline. Representative traces obtained at $1 \mathrm{~min}$ before HFS and $60 \mathrm{~min}$ after HFS. A solid arrow indicates when HFS was given. $\boldsymbol{D}$, Induction of LTP in the presence of NMDAR antagonist MK801 in control mice and seipin-nKO mice. $\boldsymbol{E}$, Induction of LTP in control mice and seipin-nKO mice treated with rosi for $3 \mathrm{~d}$. $\boldsymbol{F}$, Induction of LTP after the rosi application for 30 min in slices obtained from seipin-nKO mice. 

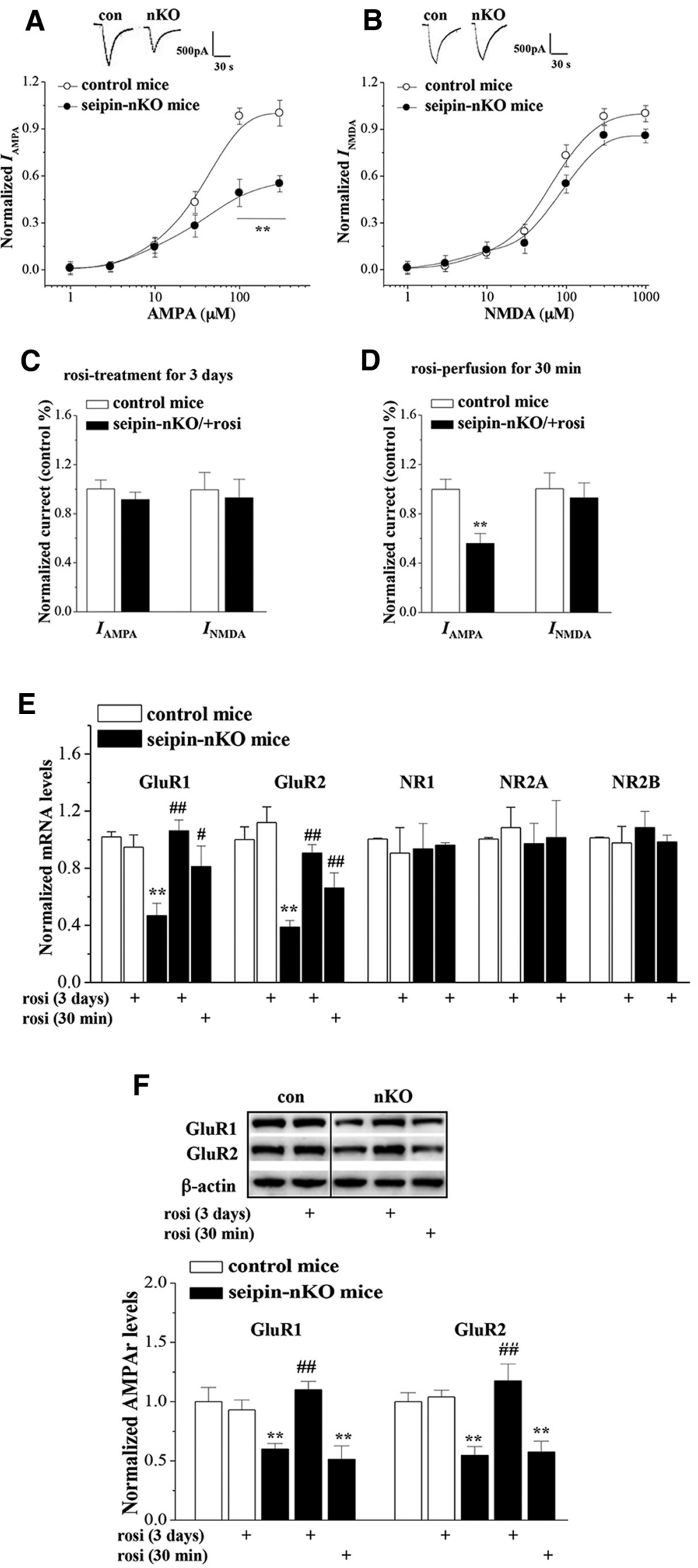

Figure 4. Treatment with rosi rescues seipin-deficiency-induced AMPAR downregulation. $A$, Dose-response curves of $I_{\text {AMPA }}$ in control mice and seipin-nKO mice. Each point represents the normalized current from 10 hippocampal CA1 pyramidal cells. Inset, Representative traces of $I_{\text {AMPA }}\left(100 \mu \mathrm{M}\right.$ AMPA). ${ }^{* *} p<0.01$ versus control mice (repeated-measures ANOVA). B, Dose-response and seipin-nKO mice. Therefore, it is conceivable that the cognitive deterioration by the seipin deficiency might be attributed to the reduction of PPAR $\gamma$.

No changes in the hippocampal size and thickness of pyramidal cell layer are found in seipin-nKO mice (Zhou et al., 2014). The seipin knock-out rats do not show a decrease in density of hippocampal neuronal cells (Ebihara et al., 2015). Neuronal PPAR $\gamma$ deficiency in mice is not sufficient to cause neuronal loss in hippocampus (Zhao et al., 2009). Notably, the efficiency of Schaffer collateral-CA1 synaptic transmission in seipin-nKO mice was significantly reduced. The mutation of seipin (N88S) has been found to reduce the synaptic release (Wei et al., 2014). The capability of presynaptic glutamate release in seipin-nKO mice was not affected, whereas the postsynaptic $I_{\mathrm{AMPA}}$ was obviously reduced. The functional AMPAR expression is regulated by transcriptional and RNA editing mechanisms. The AMPAR is synthesized dendritically and inserted into synaptic membrane (Ju et al., 2004). The levels of hippocampal GluR1/ GluR2 mRNAs and GluR1/GluR2 proteins were lower in seipin-nKO mice than those in control mice. The activation of NMDAR is known to inhibit the transcription of GluR2, leading to a decrease in dendritic and synaptic AMPAR numbers (Grooms et al., 2006). Seipin deficiency did not affect the postsynaptic $I_{\mathrm{NMDA}}$. In addition, postsynaptic density-95 (PSD95) and transmembrane AMPAR regulatory proteins (TARPs) differentially interact with C-terminal end of GluR2 subunit to affect its expression (Bassani et al., 2013). In hippocampus of seipin-nKO mice, the levels of PSD95 and TARP $\gamma$-2 showed no significant difference from control mice (data not shown). In addition, the functional

$\leftarrow$

curves of $I_{\text {NMDA }}$ in control mice and seipin-nKO mice. Inset, Representative traces of $/_{\text {NMDA }}(300 \mu \mathrm{M} N M D A) . \boldsymbol{C}, \boldsymbol{D}$, Influence of rosi treatment for $3 \mathrm{~d}$ or rosi application for $30 \mathrm{~min}$ on $I_{\text {AMPA }}$ $\left(100 \mu \mathrm{M}\right.$ AMPA) and $I_{\text {NMDA }}(300 \mu \mathrm{M}$ NMDA). Bars show the mean values of $I_{A M P A}$ and $I_{\text {NMDA }}$ normalized by controls. $E$, Bars show the levels of GluR1, GluR2, NR1, NR2A, and NR2B mRNA in control mice and seipin-nK0 mice or slices treated with rosi for $3 \mathrm{~d}$ or $30 \mathrm{~min}$. The levels of mRNA are normalized by control values. ${ }^{* *} p<0.01$ versus control mice; $\# p<0.05$, \#\#p $<$ 0.01 versus seipin-nK0 mice (two-way ANOVA). $\boldsymbol{F}$, Bars show the levels of GluR1 and GluR2 protein in control mice and seipin-nKO mice or slices treated with rosi for $3 \mathrm{~d}$ or $30 \mathrm{~min}$. Densitometric values for Western blots of protein are normalized to the amounts of $\beta$-actin and then normalized again by control values. ${ }^{* *} p<0.01$ versus control mice; \#\#p $<0.01$ versus seipin-nKO mice (two-way ANOVA). 
A
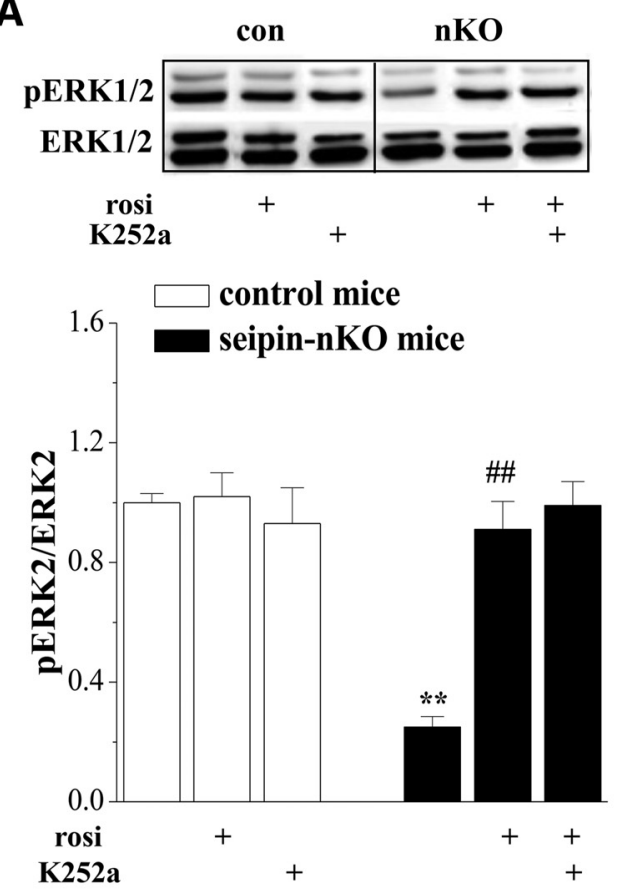

B

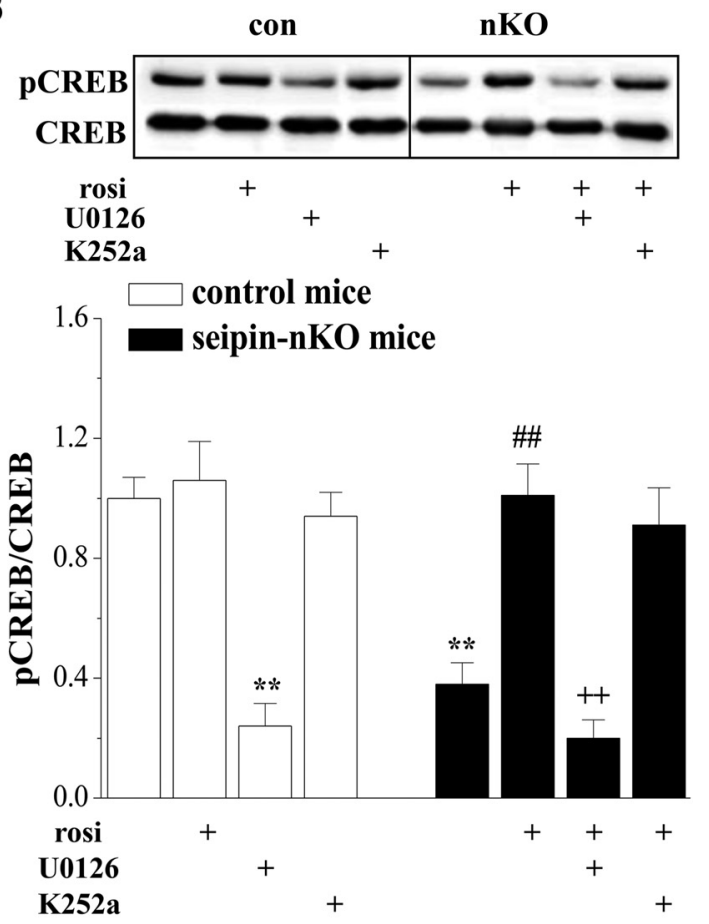

C

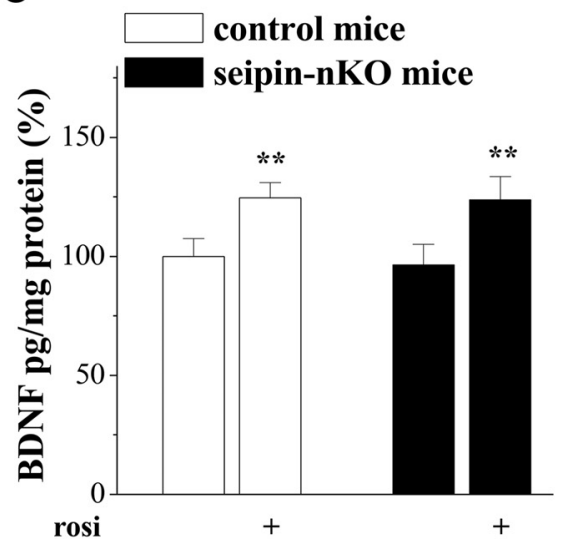

Figure 5. Treatment with rosi rescues seipin-deficiency-reduced ERK-CREB activities. $A, B$, Bars show the levels of hippocampal phosphor-ERK1/2 and phosphor-CREB in control mice and seipin-nK0 mice treated with rosi, U0126, or K252a. ${ }^{* *} p<0.01$ versus control mice; \#\#p $<0.01$ versus seipin-nK0 mice; $++p<0.01$ versus rosi-treated seipin-nK0 mice (two-way ANOVA). $C$, Bars show the level of hippocampal BDNF in control mice and seipin-nKO mice treated with rosi or vehicle. ${ }^{* *} p<0.01$ versus control mice (two-way ANOVA).

AMPAR number is regulated by their trafficking between endoplasmic reticulum to postsynaptic membrane via Golgi bodies. Wei et al. (2013) reported that seipin had no effects on the AMPAR trafficking. Therefore, the knock-down of the seipin gene in neuronal cells does not affect the inserting ability of AMPAR (Wei et al., 2014). Importantly, rosi treatment for $3 \mathrm{~d}$ in seipin-nKO mice restored AMPAR expression and recovered $I_{\mathrm{AMPA}}$ and synaptic efficiency. In contrast, acute treatment with rosi for $30 \mathrm{~min}$ failed to alter the reduction of $I_{\mathrm{AMPA}}$ andsynaptic efficiency in seipin-nKO mice but partially increased the GluR1/GluR2 mRNAs. The findings indicate that seipin deficiency suppresses the transcription of GluR1/ GluR2, leading to the downregulation of AMPAR, which can be rescued by the activation of $\operatorname{PPAR} \gamma$.

The inhibition of PPAR $\gamma$ can significantly decrease ERK2 activation (Denner et al., 2012). rosi treatment can increase nuclear ERK2 activity, as noted by an increase in Thr202/Tyr204 phos- phorylated ERK2. Hippocampal ERK2 and CREB phosphorylation in seipin-nKO mice was significantly reduced, which could be corrected by rosi treatment. The transcription factor CREB is known to regulate the expression of GluR1. ERK-CREB phosphorylation can upregulate AMPAR function (Qin et al., 2005). The decline of CREB phosphorylation is associated with a specific reduction in postsynaptic GluR1 (Borges and Dingledine, 2001). The MEK inhibitor U0126 could abolish the rosi-corrected reduction of CREB phosphorylation, AMPAR expression, and $I_{\mathrm{AMPA}}$ in seipin-nKO mice. In addition, the inhibition of ERK by U0126 could attenuate the AMPAR expression and function in control mice. The results indicate that the seipin deficiency reduces the transcription of GluR1/GluR2 though reducing the ERK-CREB phosphorylation. Conversely, the activation of PPAR $\gamma$ is able to elevate BDNF concentration through enhancing the BDNF promoter (Wang et al., 2011; Kariharan et al., 2015). rosi treatment in seipin-nKO mice could increase the concentra- 
A

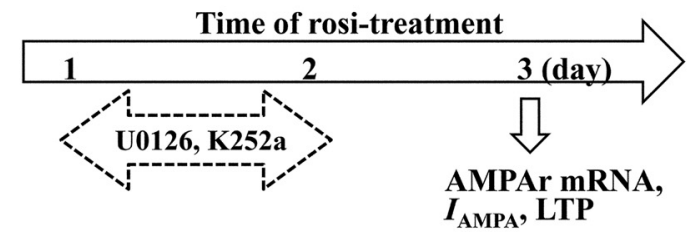

B

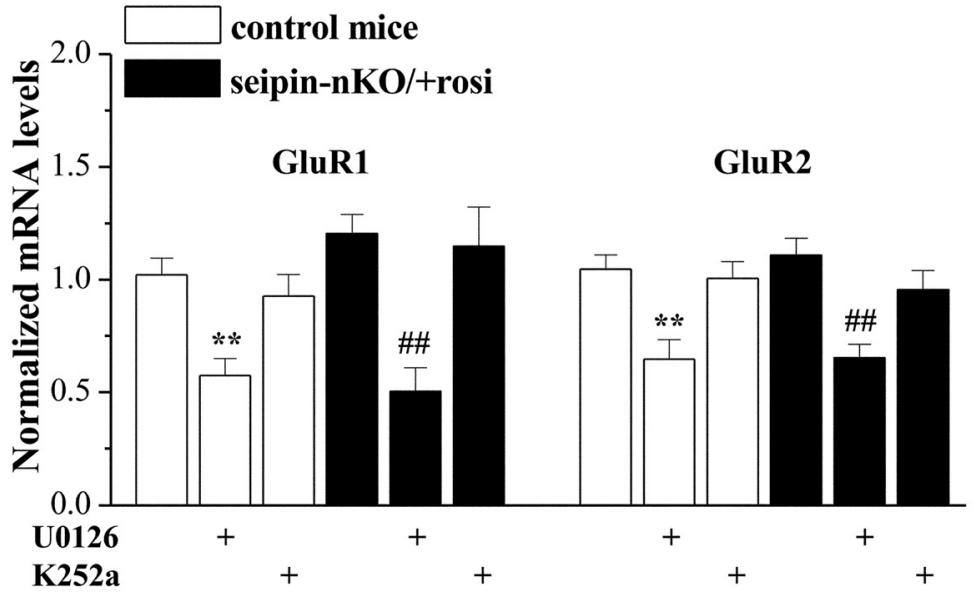

C

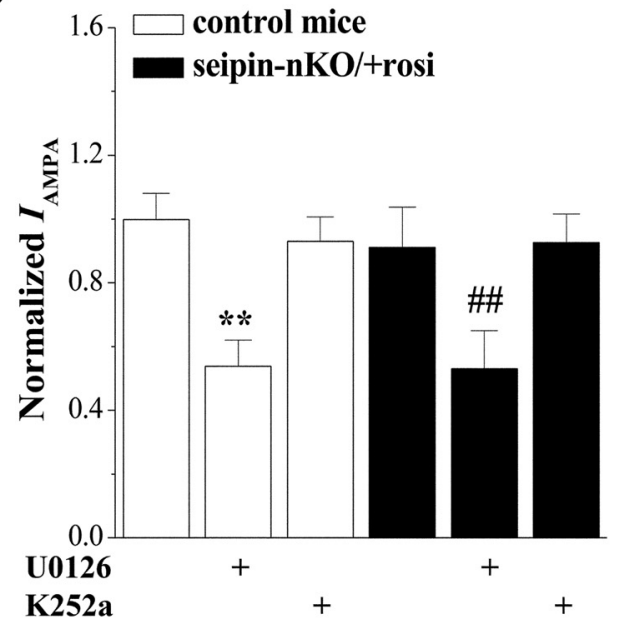

D

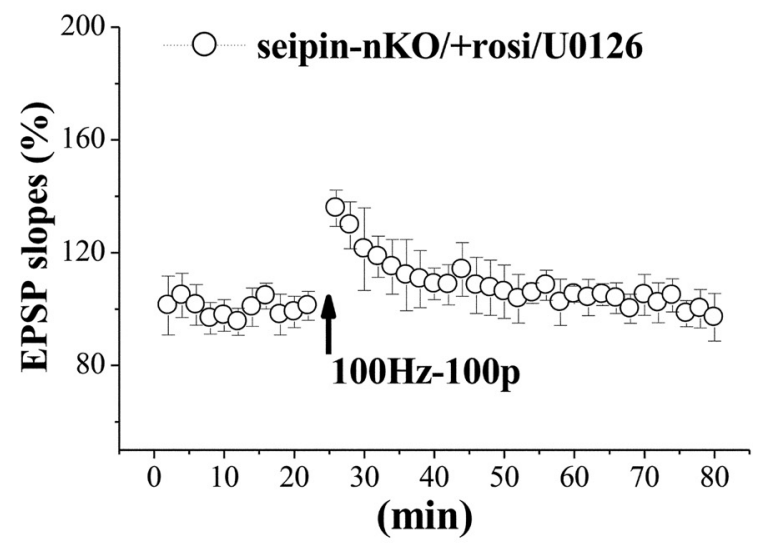

Figure 6. Seipin-deficiency-reduced ERK-CREB signaling impairs AMPAR and LTP. $A$, Time chart of experimental procedure. $B$, Effects of U0126 or K252a on rosi-restored AMPAR expression. Bars show the levels of GluR1 and GluR2 mRNA in control mice and seipin-nKO mice treated with rosi, U0126, or K252a. ${ }^{* *} p<0.01$ versus control mice; \#\#p $<0.01$ versus seipin-nK0 mice with rosi (two-way ANOVA). C, Effects of U0126 or K252a on rosi-restored $I_{\text {AMPA }}$ in seipin-nK0 mice. Bars show $I_{\text {AMPA }}(100 \mu \mathrm{M}$ AMPA) in hippocampal CA1 pyramidal cells in control mice and seipin-nK0 mice treated with rosi, U0126, or K252a. ** $<0.01$ versus control mice; \#\#p $<0.01$ versus seipin-nKO mice with rosi (two-way ANOVA). D, Effects of U0126 on rosi-restored LTP induction in seipin-nK0 mice.

tion of hippocampal mature BDNF, although seipin deficiency did not affect the BDNF level. BDNF has been reported to enhance the transcription activity of GluR1/GluR2 (Schratt et al., 2004; Caldeira et al., 2007), the transport of mRNAs along dendrites, and their translation at the synapse (Santos et al., 2010). However, the Trk family inhibitor K252a did not affect the rosicorrected reduction of AMPAR expression and $I_{\mathrm{AMPA}}$ in seipinnKO mice. A recent study (Reimers et al., 2014) has reported the bidirectional effects of BDNF on AMPAR surface expression, depending on duration of exposure. The acute $(30 \mathrm{~min})$ treatment with BDNF can increase the cellular surface GluR1/GluR2, whereas the long-term $(24 \mathrm{~h})$ treatment produces an opposite effect. Therefore, the contradictory results may arise from the difference in the experimental timing. In addition, the AMPAR is assembled in the endoplasmic reticulum (ER) (Rubio and Wenthold, 1999). GluR2 colocalizes with the ER chaperone BiP (Greger et al., 2002). Ito et al. (2008) reported that the mutations (N88S/S90L) of the seipin gene could cause the formation of cytoplasmic inclusions and enhance ubiquitination, leading to ER stress. This idea is not supported because the levels of the ER stress makers BiP and CHOP in the hippocampus of seipin-nKO mice are not elevated (Zhou et al., 2014).

The AMPAR-containing GluR2 subunit is selectively permeable to $\mathrm{Na}^{+}$and $\mathrm{K}^{+}$, accumulating evidence suggests that AMPAR plays important role during genesis of LTP in excitatory 
neurons (Santos et al., 2009; Schwenk et al., 2014). The LTP induction is impaired in GluR1 knock-out mice (Zamanillo et al., 1999), but not in double knock-out mice of both GluR2 and GluR3 (Meng et al., 2003). The reduction of AMPAR population on the hippocampal postsynaptic membrane may lead to poor development of LTP. Disruption of the interaction between GluR1 and some proteins (e.g., actin-binding protein $4.1 \mathrm{~N}$ or the activator protein 2) can block the activity-dependent LTP (Shi et al., 2001). Several lines of evidence suggest that the ERK-CREB signaling pathway is critical for the NMDAR-dependent LTP induction and many forms of learning and memory (Sweatt, 2004). Chronic treatment with rosi can correct a downregulated ERK signal transduction pathway in Tg2576 mice to overcome their cognitive deficits (Denner et al., 2012). CREB, as a nuclear coactivator of PPAR $\gamma$ (Bugge et al., 2009; Inoue et al., 2012), integrates the convergence of the PPAR $\gamma$ and ERK pathways to rescue learning and memory deficits in AD mouse models (Caccamo et al., 2010). Therefore, the impairment of NMDAR-dependent LTP in seipin-nKO mice is due to the downregulation of AMPAR and ERK-CREB signaling.

In conclusion, the present study provides evidence that the activation of PPAR $\gamma$ by rosi treatment could rescue the hippocampal LTP and spatial cognitive deficits in seipin-sKO mice and seipin-nKO mice. rosi treatment has been reported to enhance cognition in AD mice (Denner et al., 2012). Moreover, rosi treatment in type 2 diabetic mice significantly improves spatial memory and LTP induction without improvement of peripheral insulin sensitivity (Kariharan et al., 2015). The findings indicate that this nuclear receptor is a potential therapeutic target for the cognitive deficits. This idea is strengthened by the fact that PPAR $\gamma$ is reduced in AD brain and certain polymorphisms in the PPAR $\gamma$ gene are associated with increased risk for the cognitive and intellectual impairment (Kitamura et al., 1999; Scacchi et al., 2007). Similarly, the decline of hippocampal PPAR $\gamma$ level was observed in seipin-sKO mice or seipin-nKO mice. rosi treatment in seipin-sKO mice or seipin-nKO mice can alleviate their anxiety- and depression-like phenotypes (Zhou et al., 2014). Furthermore, rosi treatment can protect the impairment of adult neurogenesis in hippocampal dentate gyrus of seipin-nKO mice (Li et al., 2015). Although much more work needs to be conducted, our results in this study indicate the therapeutic possibility of the PPAR $\gamma$ agonist on mental retardation in CGL2 patients.

\section{References}

Agarwal AK, Garg A (2006) Genetic basis of lipodystrophies and management of metabolic complications. Annu Rev Med 57:297-311. CrossRef Medline

Agarwal AK, Arioglu E, De Almeida S, Akkoc N, Taylor SI, Bowcock AM, Barnes RI, Garg A (2002) AGPAT2 is mutated in congenital generalized lipodystrophy linked to chromosome 9q34. Nat Genet 31:21-23. CrossRef Medline

Bassani S, Folci A, Zapata J, Passafaro M (2013) AMPAR trafficking in synapse maturation and plasticity. Cell Mol Life Sci 70:4411-4430. CrossRef Medline

Borges K, Dingledine R (2001) Functional organization of the GluR1 glutamate receptor promoter. J Biol Chem 276:25929-25938. CrossRef Medline

Bugge A, Grøntved L, Aagaard MM, Borup R, Mandrup S (2009) The PPARgamma2 A/B-domain plays a gene-specific role in transactivation and cofactor recruitment. Mol Endocrinol 23:794-808. CrossRef Medline

Caccamo A, Maldonado MA, Bokov AF, Majumder S, Oddo S (2010) CBP gene transfer increases BDNF levels and ameliorates learning and memory deficits in a mouse model of Alzheimer's disease. Proc Natl Acad Sci U S A 107:22687-22692. CrossRef Medline

Caldeira MV, Melo CV, Pereira DB, Carvalho R, Correia SS, Backos DS,
Carvalho AL, Esteban JA, Duarte CB (2007) Brain-derived neurotrophic factor regulates the expression and synaptic delivery of alpha-amino-3-hydroxy-5-methyl-4-isoxazole propionic acid receptor subunits in hippocampal neurons. J Biol Chem 282:12619-12628. CrossRef Medline

Camarena V, Kobayashi M, Kim JY, Roehm P, Perez R, Gardner J, Wilson AC, Mohr I, Chao MV (2010) Nature and duration of growth factor signaling through receptor tyrosine kinases regulates HSV-1 latency in neurons. Cell Host Microbe 8:320-330. CrossRef Medline

Chen W, Yechoor VK, Chang BH, Li MV, March KL, Chan L (2009) The human lipodystrophy gene product Berardinelli-Seip congenital lipodystrophy $2 /$ seipin plays a key role in adipocyte differentiation. Endocrinology 150:4552-4561. CrossRef Medline

Chen W, Chang B, Saha P, Hartig SM, Li L, Reddy VT, Yang Y, Yechoor V, Mancini MA, Chan L (2012) Berardinelli-seip congenital lipodystrophy $2 /$ seipin is a cell-autonomous regulator of lipolysis essential for adipocyte differentiation. Mol Cell Biol 32:1099-1111. CrossRef Medline

Cui X, Wang Y, Tang Y, Liu Y, Zhao L, Deng J, Xu G, Peng X, Ju S, Liu G, Yang $\mathrm{H}$ (2011) Seipin ablation in mice results in severe generalized lipodystrophy. Hum Mol Genet 20:3022-3030. CrossRef Medline

Denner LA, Rodriguez-Rivera J, Haidacher SJ, Jahrling JB, Carmical JR, Hernandez CM, Zhao Y, Sadygov RG, Starkey JM, Spratt H, Luxon BA, Wood TG, Dineley KT (2012) Cognitive enhancement with rosiglitazone links the hippocampal PPARgamma and ERK MAPK signaling pathways. J Neurosci 32:16725-16735a. CrossRef Medline

Ebihara C, Ebihara K, Aizawa-Abe M, Mashimo T, Tomita T, Zhao M, Gumbilai V, Kusakabe T, Yamamoto Y, Aotani D, Yamamoto-Kataoka S, Sakai T, Hosoda K, Serikawa T, Nakao K (2015) Seipin is necessary for normal brain development and spermatogenesis in addition to adipogenesis. Hum Mol Genet 24:4238-4249. CrossRef Medline

Greger IH, Khatri L, Ziff EB (2002) RNA editing at arg607 controls AMPA receptor exit from the endoplasmic reticulum. Neuron 34:759-772. CrossRef Medline

Grooms SY, Noh KM, Regis R, Bassell GJ, Bryan MK, Carroll RC, Zukin RS (2006) Activity bidirectionally regulates AMPA receptor mRNA abundance in dendrites of hippocampal neurons. J Neurosci 26:8339-8351. CrossRef Medline

Guo J, Qiu W, Soh SL, Wei S, Radda GK, Ong WY, Pang ZP, Han W (2013) Motor neuron degeneration in a mouse model of seipinopathy. Cell Death Dis 4:e535. CrossRef Medline

Heneka MT, Klockgether T, Feinstein DL (2000) Peroxisome proliferatoractivated receptor-gamma ligands reduce neuronal inducible nitric oxide synthase expression and cell death in vivo. J Neurosci 20:6862-6867. Medline

Inoue $\mathrm{M}$, Tanabe $\mathrm{H}$, Matsumoto $\mathrm{A}$, Takagi $\mathrm{M}$, Umegaki $\mathrm{K}$, Amagaya S, Takahashi J (2012) Astaxanthin functions differently as a selective peroxisome proliferator-activated receptor gamma modulator in adipocytes and macrophages. Biochem Pharmacol 84:692-700. CrossRef Medline

Ito D, Suzuki N (2009) Seipinopathy: a novel endoplasmic reticulum stressassociated disease. Brain 132:8-15. Medline

Ito D, Fujisawa T, Iida H, Suzuki N (2008) Characterization of seipin/ BSCL2, a protein associated with spastic paraplegia 17. Neurobiol Dis 31:266-277. CrossRef Medline

Jiang M, Gao M, Wu C, He H, Guo X, Zhou Z, Yang H, Xiao X, Liu G, Sha J (2014) Lack of testicular seipin causes teratozoospermia syndrome in men. Proc Natl Acad Sci U S A 111:7054-7059. CrossRef Medline

Ju W, Morishita W, Tsui J, Gaietta G, Deerinck TJ, Adams SR, Garner CC, Tsien RY, Ellisman MH, Malenka RC (2004) Activity-dependent regulation of dendritic synthesis and trafficking of AMPA receptors. Nat Neurosci 7:244-253. CrossRef Medline

Kariharan T, Nanayakkara G, Parameshwaran K, Bagasrawala I, Ahuja M, Abdel-Rahman E, Amin AT, Dhanasekaran M, Suppiramaniam V, Amin RH (2015) Central activation of PPAR-gamma ameliorates diabetes induced cognitive dysfunction and improves BDNF expression. Neurobiol Aging 36:1451-1461. CrossRef Medline

Kitamura Y, Shimohama S, Koike H, Kakimura Ji, Matsuoka Y, Nomura Y, Gebicke-Haerter PJ, Taniguchi T (1999) Increased expression of cyclooxygenases and peroxisome proliferator-activated receptor-gamma in Alzheimer's disease brains. Biochem Biophys Res Commun 254:582-586. CrossRef Medline

Li G, Zhou L, Zhu Y, Wang C, Sha S, Xian X, Ji Y, Liu G, Chen L (2015) Seipin knock-out in mice impairs stem cell proliferation and progenitor 
cell differentiation in the adult hippocampal dentate gyrus via reduction of PPAR $\gamma$. Dis Model Mech 8:1615-1624. Medline

Li L, Qu W, Zhou L, Lu Z, Jie P, Chen L, Chen L (2013a) Activation of transient receptor potential Vanilloid 4 increases NMDA-activated current in hippocampal pyramidal neurons. Front Cell Neurosci 7:17. Medline

Li L, Yin J, Jie PH, Lu ZH, Zhou LB, Chen L, Chen L (2013b) Transient receptor potential vanilloid 4 mediates hypotonicity-induced enhancement of synaptic transmission in hippocampal slices. CNS Neurosci Ther 19:854-862. CrossRef Medline

Liu L, Jiang Q, Wang X, Zhang Y, Lin RC, Lam SM, Shui G, Zhou L, Li P, Wang Y, Cui X, Gao M, Zhang L, Lv Y, Xu G, Liu G, Zhao D, Yang H (2014) Adipose-specific knockout of SEIPIN/BSCL2 results in progressive lipodystrophy. Diabetes 63:2320-2331. CrossRef Medline

Magré J, Delépine M, Khallouf E, Gedde-Dahl T Jr, Van Maldergem L, Sobel E, Papp J, Meier M, Mégarbané A, Bachy A, Verloes A, d'Abronzo FH, Seemanova E, Assan R, Baudic N, Bourut C, Czernichow P, Huet F, Grigorescu F, de Kerdanet M, et al.; BSCL Working Group. (2001) Identification of the gene altered in Berardinelli-Seip congenital lipodystrophy on chromosome 11q13. Nat Genet 28:365-370. CrossRef Medline

Maurice T, Lockhart BP, Privat A (1996) Amnesia induced in mice by centrally administered beta-amyloid peptides involves cholinergic dysfunction. Brain Res 706:181-193. CrossRef Medline

Meng Y, Zhang Y, Jia Z (2003) Synaptic transmission and plasticity in the absence of AMPA glutamate receptor GluR2 and GluR3. Neuron 39: 163-176. CrossRef Medline

Moreno S, Farioli-Vecchioli S, Cerù MP (2004) Immunolocalization of peroxisome proliferator-activated receptors and retinoid $\mathrm{X}$ receptors in the adult rat CNS. Neuroscience 123:131-145. CrossRef Medline

Murakami N, Hayashi YK, Oto Y, Shiraishi M, Itabashi H, Kudo K, Nishino I, Nonaka I, Nagai T (2013) Congenital generalized lipodystrophy type 4 with muscular dystrophy: clinical and pathological manifestations in early childhood. Neuromuscul Disord 23:441-444. CrossRef Medline

Prieur X, Dollet L, Takahashi M, Nemani M, Pillot B, Le May C, Mounier C, Takigawa-Imamura H, Zelenika D, Matsuda F, Fève B, Capeau J, Lathrop M, Costet P, Cariou B, Magré J (2013) Thiazolidinediones partially reverse the metabolic disturbances observed in Bscl2/seipin-deficient mice. Diabetologia 56:1813-1825. CrossRef Medline

Qin Y, Zhu Y, Baumgart JP, Stornetta RL, Seidenman K, Mack V, van Aelst L, Zhu JJ (2005) State-dependent Ras signaling and AMPA receptor trafficking. Gene Dev 19:2000-2015. CrossRef Medline

Rajab A, Khaburi M, Spranger S, Kunze J, Spranger J (2003) Congenital generalized lipodystrophy, mental retardation, deafness, short stature, and slender bones: a newly recognized syndrome? Am J Med Genet A 121A:271-276. CrossRef Medline

Reimers JM, Loweth JA, Wolf ME (2014) BDNF contributes to both rapid and homeostatic alterations in AMPA receptor surface expression in nucleus accumbens medium spiny neurons. Eur J Neurosci 39:1159-1169. CrossRef Medline

Rubio ME, Wenthold RJ (1999) Calnexin and the immunoglobulin binding protein $(\mathrm{BiP})$ coimmunoprecipitate with AMPA receptors. J Neurochem 73:942-948. Medline

Salehi-Sadaghiani M, Javadi-Paydar M, Gharedaghi MH, Zandieh A, Heydarpour P, Yousefzadeh-Fard Y, Dehpour AR (2012) NMDA receptor involvement in antidepressant-like effect of pioglitazone in the forced swimming test in mice. Psychopharmacology (Berl) 223:345-355. CrossRef Medline

Santos AR, Comprido D, Duarte CB (2010) Regulation of local translation at the synapse by BDNF. Prog Neurobiol 92:505-516. CrossRef Medline

Santos SD, Carvalho AL, Caldeira MV, Duarte CB (2009) Regulation of AMPA receptors and synaptic plasticity. Neuroscience 158:105-125. CrossRef Medline

Scacchi R, Pinto A, Gambina G, Rosano A, Corbo RM (2007) The peroxisome proliferator-activated receptor gamma (PPAR-gamma2) Pro12Ala polymorphism is associated with higher risk for Alzheimer's disease in octogenarians. Brain Res 1139:1-5. CrossRef Medline
Schratt GM, Nigh EA, Chen WG, Hu L, Greenberg ME (2004) BDNF regulates the translation of a select group of mRNAs by a mammalian target of rapamycin-phosphatidylinositol 3-kinase-dependent pathway during neuronal development. J Neurosci 24:7366-7377. CrossRef Medline

Schuster J, Khan TN, Tariq M, Shaiq PA, Mäbert K, Baig SM, Klar J (2014) Exome sequencing circumvents missing clinical data and identifies a BSCL2 mutation in congenital lipodystrophy. BMC Med Genet 15:71. Medline

Schwenk J, Baehrens D, Haupt A, Bildl W, Boudkkazi S, Roeper J, Fakler B, Schulte U (2014) Regional diversity and developmental dynamics of the AMPA-receptor proteome in the mammalian brain. Neuron 84:41-54. CrossRef Medline

Shi S, Hayashi Y, Esteban JA, Malinow R (2001) Subunit-specific rules governing AMPA receptor trafficking to synapses in hippocampal pyramidal neurons. Cell 105:331-343. CrossRef Medline

Sweatt JD (2004) Mitogen-activated protein kinases in synaptic plasticity and memory. Curr Opin Neurobiol 14:311-317. CrossRef Medline

Szymanski KM, Binns D, Bartz R, Grishin NV, Li WP, Agarwal AK, Garg A, Anderson RG, Goodman JM (2007) The lipodystrophy protein seipin is found at endoplasmic reticulum lipid droplet junctions and is important for droplet morphology. Proc Natl Acad Sci U S A 104:20890-20895. CrossRef Medline

Takeuchi T, Duszkiewicz AJ, Morris RG (2014) The synaptic plasticity and memory hypothesis: encoding, storage and persistence. Philos Trans R Soc Lond B Biol Sci. 369:20130288. CrossRef Medline

Tsai YW, Yang YR, Wang PS, Wang RY (2011) Intermittent hypoxia after transient focal ischemia induces hippocampal neurogenesis and c-Fos expression and reverses spatial memory deficits in rats. PLoS One 6:e24001. CrossRef Medline

Van Maldergem L, Magré J, Khallouf TE, Gedde-Dahl T Jr, Delépine M, Trygstad O, Seemanova E, Stephenson T, Albott CS, Bonnici F, Panz VR, Medina JL, Bogalho P, Huet F, Savasta S, Verloes A, Robert JJ, Loret H, De Kerdanet M, Tubiana-Rufi N, et al. (2002) Genotype-phenotype relationships in Berardinelli-Seip congenital lipodystrophy. J Med Genet 39: 722-733. CrossRef Medline

Wang L, Zhang L, Chen ZB, Wu JY, Zhang X, Xu Y (2009) Icariin enhances neuronal survival after oxygen and glucose deprivation by increasing SIRT1. Eur J Pharmacol 609:40-44. CrossRef Medline

Wang SH, Guo YJ, Yuan Y, Li L, Li FF, Ye KP, Huang Y (2011) PP ARgamma-mediated advanced glycation end products regulate neural stem cell proliferation but not neural differentiation through the BDNFCREB pathway. Toxicol Lett 206:339-346. CrossRef Medline

Wei S, Soh SL, Qiu W, Yang W, Seah CJ, Guo J, Ong WY, Pang ZP, Han W (2013) Seipin regulates excitatory synaptic transmission in cortical neurons. J Neurochem 124:478-489. CrossRef Medline

Wei S, Soh SL, Xia J, Ong WY, Pang ZP, Han W (2014) Motor neuropathyassociated mutation impairs Seipin functions in neurotransmission. J Neurochem 129:328-338. CrossRef Medline

Yang R, Chen L, Wang H, Xu B, Tomimoto H, Chen L (2012) Anti-amnesic effect of neurosteroid PREGS in Abeta25-35-injected mice through sigmal receptor- and alpha7nAChR-mediated neuroprotection. Neuropharmacology 63:1042-1050. CrossRef Medline

Zamanillo D, Sprengel R, Hvalby O, Jensen V, Burnashev N, Rozov A, Kaiser KM, Köster HJ, Borchardt T, Worley P, Lübke J, Frotscher M, Kelly PH, Sommer B, Andersen P, Seeburg PH, Sakmann B (1999) Importance of AMPA receptors for hippocampal synaptic plasticity but not for spatial learning. Science 284:1805-1811. CrossRef Medline

Zhao X, Strong R, Zhang J, Sun G, Tsien JZ, Cui Z, Grotta JC, Aronowski J (2009) Neuronal PPARgamma deficiency increases susceptibility to brain damage after cerebral ischemia. J Neurosci 29:6186-6195. CrossRef Medline

Zhou L, Yin J, Wang C, Liao J, Liu G, Chen L (2014) Lack of seipin in neurons results in anxiety- and depression-like behaviors via down regulation of PPARgamma. Hum Mol Genet 23:4094-4102. CrossRef Medline 